$(a)$ associations, $(b)$ relative abundance, $(c)$ specific identity, and $(d)$ characteristics of inclusions. The ultimate value still rests on " coincidences", and may establish nothing more than a probability, which, to carry conviction, must be supported by numerous coincidences.

"Eocene and Pliocene Outliers between Chipstead and Headley, Surrey." By A. W. Groves, M.Sc., D.I.C.

A description is given of a Tertiary outlier, previously considered to be largely Clay with Flints, resting on the Upper Chalk of the North Downs. It is dissected by a number of dry valleys in the Chalk. With the exception of the southern boundary, which is very obscure, the limits have been mapped on the 6 in. scale. It consists of Thanet Sand and Lenham Beds, and, in addition, there are probably some remnants of Woolwich and Reading Beds. Some Eocene pebbles may indicate the former existence of Blackheath Beds. The deposits lie on a very uneven surface resulting from postThanetian solution of the Chalk. At the base of the Thanet Sand is a solution product which has been called Grey Clay with Flints, containing black-coated Flints. Other solution phenomena are described.

The mapping and sampling show the existence of a larger area of Pliocene than has previously been recognized. The petrography of the beds is described, and, in the Lenham Beds, evidence is given to show that the Dartmoor granite supplied some part of the material.

The following paper was taken as read:-

"The Petrology of the Spilsby Sandstone." By F. T. Ingham, B.Sc., A.R.C.S., A.I.C., F.G.S.

\title{
CORRESPONDENCE.
}

\section{GEOLOGICAL SURVEY OF UGANDA}

Srr,-An unfortunate error has crept into the Annual Report of the Geological Survey of Uganda for the year 1926, whereby the reader is informed that Mr. A. D. Combe, of this Survey, is of opinion that there is a continuous succession through the Transvaal System into the Waterberg System in the Cape Province of South Africa. May I be permitted to make use of your Journal to correct this, please? Perhaps those of your readers who have copies of the report will kindly turn up page 32 , delete line 34 , and delete all of line 35 except the last word and the comma in front of it and rewrite so as to read :-

"Mr. Combe suggests that in the Katanga Province there may be a continuous conformable succession through the equivalents of the Transvaal and Waterberg Systems without an unconformity, similar to the grand conformable succession, in parts of the Cape Province through the Cape and Karroo Systems."

William C. Simmons. 